\title{
Bandırma Taş Ocakları ve Ermeniler
}

\section{Quarries in Bandirma and Armenians}

\author{
Recep Karacakaya* (i)
}

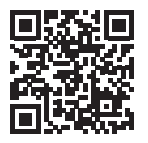

*Prof. Dr., Medeniyet Üniversitesi, Edebiyat Fakültesi, Tarih Bölümü, İstanbul, Türkiye

\section{ORCID: R.K. 0000-0003-1640-7596}

Sorumlu yazar/Corresponding author: Recep Karacakaya,

Medeniyet Üniversitesi, Edebiyat Fakültesi, Tarih Bölümü, İstanbul, Türkiye

E-posta/E-mail: recepkaracakaya@gmail.com

Başvuru/Submitted: 01.06 .2020

Revizyon Talebi/Revision Requested:

21.06.2020

Son Revizyon/Last Revision Received:

24.06.2020

Kabul/Accepted: 10.07 .2020

\section{Atıf/Citation:}

Karacakaya, Recep. "Bandırma Taș Ocakları ve Ermeniler." Tarih Dergisi - Turkish Journal of History, 71 (2020): 429-443.

https://doi.org/10.26650/TurkJHist.2020.020

\section{öz}

Bu makalede Bandırma'nın Preme Nahiyesi'ndeki Ermeni köyünde bulunan taş ocaklarının işletilmesi meselesi incelenecektir. Taş ocaklarının işletilmesiyle ilgili problemler yerel yönetimin, köylülere ait kullanım hakkını iptal ederek, bir yabancıya vermesi ile başlamıştır. Taş ocağının kullanım hakkını en son elde eden Gustave Couteaux, taş ocağından faydalanan Ermeni köylülerini resmi makamlara şikâyet etmiş ve Ermenilerin taş ocağını kullanmasını yasaklatmıştır. Bunun üzerine köyde, Ermenilerle taş ocağını işletenler arasında gerginlik oluşmuş, Ermeniler, taş ocağı çalışanlarına fiili saldırılarda bulunmuşlardır. Osmanlı Hükümeti gerekli tedbirleri alarak taraflar arasındaki sorunu çözmeye çalışmıştır.

Anahtar sözcükler: Bandırma, Taş ocakları, Ermeniler, Gustave Couteaux

\section{ABSTRACT}

In this paper the issue of operating the quarry located in the Armenian village of Preme district, Bandırma town, during the second constitutional era will be examined. Problems began when the local government abolished the permission that the Armenian villagers had for operating quarries and gave the operating right to a foreigner. Gustave Couteaux, a Belgian, was the last foreigner to hold this permission and he informed the Ottoman government about the Armenian villagers who were using his quarry. At the request of the operator the Ottoman government forbad Armenians to use the quarry. After this ban the disagreement between the Armenian villagers and the operators turned into a physical conflict. The Ottoman government then tried to solve the problem.

Keywords: Bandırma, Quarry, Armenians, Gustave Couteaux 


\section{Giriş}

Osmanlı döneminde önce Bursa'ya, daha sonra Karesi Sancağı'na bağlı bir kaza konumunda olan Bandırma'da imparatorluğun çoğu yerinde olduğu gibi Müslümanlarla gayrimüslim unsurlar uzun süre bir arada yaşamışlardır. Karesi Sancağı'na Ermenilerin gelip yerleşmesi, 16. yüzyılın hemen sonu ya da 17. yüzyılın başlarıdır ${ }^{1}$. Bu zaman dilimi içinde bölgeye gelip yerleşen Ermeniler, kısa süre içerisinde yerli Müslüman ahali ile iyi ilişkiler kurmuş, esnaflık ve ticaretle uğraşmışlar, 17. yüzyılın ikinci yarısında şehirde müstakil bir kiliseye sahip olmuşlardır².

Ermenilerin Bandırma'ya yerleşmesi ise, 17. yüzyılın ortalarında olmuştur. 1914 yılı nüfus verilerine göre, Bandırma'da 56.378 Müslüman, 5.126 Ermeni, 106 Katolik Ermeni, 42.542 Rum ve 307 Musevi yaşamakta idi³.

Taş ocaklarının bulunduğu Bandırma'nın Preme nahiyesindeki Ermeni köyünde 230 hane bulunmaktaydı ve köy ahalisinin 190 hanesi taş işiyle uğraşmaktaydı. Köyün nüfusu 1.500 kişiden ibaretti ${ }^{4}$.

\section{Taş Ocaklarının Hukuki Statüsü}

Osmanlı Devleti'nin taş ocaklarıyla ilgili yaptığı ilk düzenleme 28 Mayıs 1861 tarihli Maden Nizamnamesi'nin içinde yer almıştır. Madenlerin "mevadd-1 madeniye" ve "mevadd-1 gayr-1 madeniye ${ }^{6 "}$ olarak sınıflandırıldı̆̆ı nizamnâme ile maden arama ruhsatları belli bir prosedüre bağlanırken, imtiyaz alan kişilerin ödeyecekleri vergiler, maden üretilirken uyulması gereken kurallar da belirlenmiştir? ${ }^{7}$ Bu maden nizamnamesi ile taş ocakları Mevadd-1 Gayr-1 Madeniye sınıfına dahil edilmiştir.

1 Murat Öntuğ, "Balıkesir'deki Ermeni Kilisesi ve Mektep Açma Faaliyetleri”, OTAM, sayı 19, 2006 , s. 344.

2 Öntuğ, a.g.m., s. 349-350.

3 Memalik-i Osmaniyye'nin 1330 Senesi Nüfus İstatistiği, Dersaadet 1336, s. 32, 33.

4 BOA, ŞD, 548/35-4; Anadolu çok sayıda tarihi taş ocağına sahiptir. Selçuklu ve Osmanlı İmparatorluğu dönemlerinde taş ocakları faaliyetlerine devam etmiştir. Taş ocaklarından çıkarılan taşlar köprü, kervansaray, cami, kilise, kümbet, şifahane, medrese gibi yapılarda hem yapı hem de süsleme taşı olarak kullanılmıştır. Yapı taşı olarak büyük öneme sahip granit taşının Türkiye'de çıkarıldığı yerlerden birisi de Kapıdağ Yarımadası'nın batısıdır. Makalenin konusu olan bu bölgedeki taş ocaklarından çıkan granitler uzun yıllar İstanbul civarında parke ve bordür taşı olarak kullanılmıştır. Bkz. Nuran Taşlıgil-Güven Şahin, "Yapı Malzemesi Olarak Kullanılan Türkiye Doğal Taşlarının İktisadi Coğrafya Odağında Analizi”, Marmara Coğrafya Dergisi, sayı 33, Ocak 2016, s. 625-626.

5 Mevadd-1 Madeniyye; gerek yeryüzünde ve gerekse yeraltında bulunan altın gümüş, kurşun, bakır, kalay, nikel, civa, çinko, manganez, krom, kükürt, kobalt, zımpara, şap, maden kömürü ve kaya tuzu olarak tanımlanmıştı.

6 Mevadd-ı Gayr-1 Madeniye; mermer, çakmak ve alçı taşı, kireç, porselen toprağı, kum, kil, lüle yapımında kullanılan toprak ve taş çeşitleri olarak tanımlanmıştı.

7 Özkan Keskin, “Osmanlı Devleti’nde Maden Hukukunun Tekamülü (1861-1906)”, OTAM, sayı 29, Ankara 2011, s. 127-130; Nesrin Kanberoğlu, “Osmanlı Devletinin Zımpara Madenleri Hakkında Bir Tetkik (19081918)”, Journal of History Studies, c. X, Kasim 2018, s. 188. 
1869 yılında yeni bir Maden Nizamnamesi hazırlanmıştır. 1869 nizamnamesi, 1861 tarihli nizamnameye göre daha kapsamlıydı ve madenlerin tanımı ve sınıflandırması yapılmıştı. Yeni nizamname ile madenler "maadin-i asliye", "maadin-i sathiye" ve "taş ocakları" olmak üzere üç kısma bölünmüştür. 1869 nizamnamesiyle taş ocakları maden sayılmamış, toprak mülkiyetine sahip olan kişiler, taş ocağını işletme hakkına sahip olmuştur. Osmanlı Devleti’nin hazırladığı ve II. Meşrutiyet Döneminde kullanılan geniş ve ayrıntılı son nizamname 1906 tarihli Maden Nizamnamesi olmuştur. $\mathrm{Bu}$ nizamnamede madenlerin tasnifi, yabancıların maden ihalesi alabilmeleri, madeni keşfedene verilecek mucitlik hakkı gibi hükümler değişmeden kalmıştır. 1869 yılında üç kısma ayrılmış olan madenler 1906 Maden Nizamnamesi'nde de "maadin-i asliye", "maadin-i sathiye" ve "taş ocakları" ismiyle üç kısım olarak yerini almıştır8. 1906 Maden Nizamnamesi’nde de taş ocakları ayrı bir kategori olarak değerlendirilmiştir.

\section{Taş Ocaklarının İşletilmesiyle İlgili Problemlerin Ortaya Çıkmaya Başlaması}

Bandırma kazasında bulunan taş ocaklarıyla ilgili problemlerin, taş ocaklarının işletme hakkının yabancılara verilmesi ile ortaya çıktığı görülmektedir. Taş ocakları Bandırma kazasına bağlı Preme Nahiyesi’ndeki Ermeni köyünde bulunmaktadır.

Köyün üzerinde bulunduğu arazi, Sultan Bayezid-i Velî vakfına aittir. Taş ocaklarının üzerinde bulunduğu arazi sonraki yıllarda Ermeni Kilisesi vakfina, vakıf mütevellisi Manuk adına verilmiştir. Köy ahalisi imal ve ihraç ettikleri taşları İstanbul, Edirne ve sair Osmanlı şehirlerine nakletmekteydiler?

Ermeni köyü hududu dahilinde 7 adet taş ocağı bulunmaktadır. Bu ocaklar, Balaban, Bakraç, Eskiköy, Çınar, Demirci, Dere ve Yalı adlarındaki ocaklardır ${ }^{10}$.

Köyde ilk defa İtalyan tebaasından Karabella, Ermenilerle birlikte taş ocakları işletmeye başlamıştır. Ermeni karyesinde bulunan taş ocakları için, kilise mütevellisi Burgaz oğlu Manuk adına ilmuhaberler verilmişti. Daha sonra Bursa eski valisi Mahmud Celaleddin Paşa tarafından, köylülere verilen ilmuhaberler iptal edilmiştir. 11 Temmuz 1306/23 Temmuz 1890 tarihinde bu arazinin kimsenin uhdesinde olmadığı ve "arazi-i hâliyeden" olduğu belirtilerek taş ocaklarıyla ilgili ruhsatname İtalyan vatandaşı Tinos Karabella'ya verilmiş ve bu tarihten sonra taraflar arasında anlaşmazlıklar baş göstermeye başlamıştır.

$\mathrm{Bu}$ anlaşmazlıklar idari mesele olmaktan çıkmış ve hukuki bir mesele olmuş, durum mahkemeye aksetmiştir ${ }^{11}$. Dava temyize kadar gitmiş, meselenin hukuk mahkemesinde yapılacak yargılamalar sonucu halledilmesi kararlaştırılmıştır.

8 Keskin, a.g.m., s. 130-136; Kanberoğlu, a.g.m., s. 188, 189.

9 BOA, ŞD, 548/35-4.

10 BOA, DH.MKT, 2280/39-1.

11 BOA, ŞD, 548/35-4-2. 
Taş ocaklarının ilk yabancı işletmecisi olan Tinos Karabella, Bandırma'da işletmekte olduğu granit taş ocaklarına ahali tarafından vuku bulan müdahaleden dolayı İtalya Konsoloshanesi'ne protestoname vermiştir ${ }^{12}$. Bu protesto üzerine, İtalyan Sefareti de tebaası olan Karabella'nın imaline ruhsat aldığı granit taş ocaklarına, ahali tarafından yapılan müdahalenin engellenmesi hususuna dair çeşitli tarihlerde takrirler vermiştir ${ }^{13}$.

1891 tarihinde köylüler tarafından taşların gönderilmesine güçlükler çıkarılması üzerine müdahalenin engellenmesi için vilayetten Bandırma'ya emirler verilmiştir. İşletmekte olduğu taş ocaklarına ahalinin müdahalesinden dolayı zarar ettiğini ileri süren Karabella, zararının karşılanması için 3.000 lira tazminat talebinde bulunmuş, talep incelenmek üzere Şura-yı Devlet'e gönderilmiştir. Şura-yı Devlet, yaptığı incelemeler sonucunda, bu işin anlaşma yoluyla halledilmesinin uygun olacağına karar vermiş, Karabella'nın istediği 3 maddelik tazminat talebinin 1 maddesinin tamamen ve kesinlikle reddine, diğer iki madde için 100 Osmanlı lirası ile 6.120 Frank ödenmesinin yeterli olacağına karar vermiştir ${ }^{14}$.

Karabella taş işletme işinden zarar ettiğini ileri sürerek, 13 Ağustos 1891 tarihinde taş ocağı işletme ruhsatlarını Doktor Mortman'a devretmiştirir' ${ }^{15}$ Doktor Mortman ise taş ocaklarını 1906 senesine kadar işletmiş, aynı yıl ocakları Belçika vatandaşı Couteaux kardeşlere devretmiştir. Bu devrin gerekçesini ortaya koyan belgelere rastlanmamıştır.

\section{II. Meşrutiyet Döneminde Bandırma'daki Taş Ocaklarının Durumu}

Bandırma'da Ermeni köyünde taş çıkarma meselesi, II. Meşrutiyet'in ilanından sonra tartışma konusu olmaya devam etmiştir. Bu dönemde de tartışmanın tarafları Couteaux kardeşler ve Ermeni köyünde bulunan Ermeni Kilisesi Meclisi azaları olmuştur. Her iki taraf taş ocaklarından taş çıkarıp, İstanbul'a nakletmek hakkının kendilerine ait olduğunu iddia etmişler ve bundan dolayı aralarında anlaşmazlıklar çıkmıştır.

Gustave Couteaux, sürekli olarak, taş çıkarma ruhsatına sahip olduğu taş ocaklarına ahali tarafından müdahale edildiğini, bu konudaki müracaatlarının bir sonuç vermediğini, konuyla ilgili olarak hukukunun muhafaza edilmesini ilgililerden istemektedir. Genellikle Orman, Meadin ve Ziraat Nezareti konuyla ilgilenmekte ve durumu Dahiliye Nezareti'ne bildirmektedir.

Orman, Meadin ve Ziraat Nezareti 9 Ekim 1909 tarihinde Dahiliye Nezareti'ne gönderdiği bir yazıda; iki gün önce köylüler tarafından, on bin taşın yetkililerin muhalefetine rağmen zorla gemilere yüklenerek İstanbul'a nakledildiğini, bu durumun önemli hadiselerin

12 BOA, HR.TO, 536/24-1.

13 BOA, HR.HMŞ.IŞO, 91/1-1.

14 BOA, ŞD, 1590/8-22.

15 BOA, ŞD, 1590/8-1; BOA, BEO, 2028/152057-1. 
çıkmasıyla sonuçlanabileceğini, bu konuda mahalli yetkililerce dikkatli davranılması ve ruhsatsız taş nakliyatına meydan verilmemesi gerektiğini belirtmiştir ${ }^{16}$.

Dahiliye Nezareti de durumu aynı gün bir telgrafla Karesi Mutasarrıflığı'na iletmiş, dikkatli davranılmasını, bu meseleden dolayı olay çıkmasına ve ruhsatsız taş nakliyatına izin verilmemesini istemiştir ${ }^{17}$.

Gustave Couteaux şikayetlerine devam etmiş, Dâhiliye Nezareti'ne gönderdiği 28 Ekim 1909 tarihli bir yazıda, taş ocaklarına köylülerce yapılan taarruz ve tecavüzden bahsederek, bunun önlenmesi için defalarca yaptığı müracaatlarının dikkate alınmadığını, açmış oldukları ocakları mahalli hükümetin koruyamadığını, hırsızlara karşı bizzat haklarını koruma konusunda kanunen izinli bulunduklarını, adamlarıyla ahali arasında çıkabilecek bir çatışmanın sonucundan kesinlikle sorumlu sayılamayacaklarını son defa yazdığını belirterek, acele olarak gereğinin yapılmasını rica etmiştir ${ }^{18}$.

"Bandırma kazâsında Ermeni karyesinde bâ-ruhsat-ı resmiye i'mâl etmekde olduğumuz

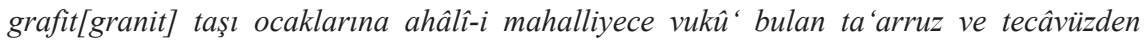
bahisle men 'i hakkinda bi'd-defe 'ât vâkî' olan mürâca 'ât-l çâkerânemiz üzerine akdemce Hüdâvendigar vilâyetine iş 'âr vuk̂े' bulduğu gibi ...”.

Gustave Couteaux'nun bu yazısı üzerine Dahiliye Nezareti, aynı gün, Karesi Mutasarrıflığı'nı uyarmış, taş ocaklarına yapılan müdahalenin kesinlikle önlenmesini, mahalli memurların bu konuda tembellik ve kayıtsızlık göstermesi durumunda haklarında gereken muamelenin yapılmasını istemiştir ${ }^{19}$.

Fakat Gustave Couteaux'nun şikâyetleri bitmemiş, bu defa da avukatı Mihran Şirinyan Efendi, Orman, Meadin ve Ziraat Nezareti'ne bir dilekçe vermiş, resmi ruhsat ile işletmekte oldukları taş ocaklarına köylüler tarafından müdahale edilerek kırk binden fazla taşın çalındığını bildirmiştir ${ }^{20}$.

Aradan bir ay geçtikten sonra, taş ocaklarından köylüler tarafından altı bin adet taşın çalındığı ve mahalli yetkililere yapılan müracaatlardan bir sonuç alınamadığını beyan eden bir arzuhal daha, 6 Nisan 1910 tarihinde Dahiliye Nezareti’ne gönderilmiştir.

Gustave Couteaux'nun Dahiliye Nezareti’ne verdiği şikâyet dilekçesinde; Bandırma Kazası'nda Ermeni köyündeki taş ocaklarına köy ahalisi tarafından yapılan tecavüz ve müdahale üzerine, bahsi geçenlerin haksızlıkları ve tecavüzlerinin önlenmesi hakkında önceden ve sonradan gerek ilgili nezarete gerek Dahiliye Nezareti'nden defalarca ve en son

16 BOA, DH.MUI, 22-2/56-2.

17 BOA, DH.MUI, 22-2/56-1.

18 BOA, DH.MUI, 22-2/56-4.

19 BOA, DH.MUI, 22-2/56-3.

20 BOA, DH.MUI, 22-2/56-7; BOA, DH.MUI, 22-2/56-8. 
olarak 7 Mart 1910 tarihinde Karesi livasına hitaben yazılan tahrirat kaza kaymakamlığına tebliğ olunmuş ise de kaymakamın gevşekliğinden dolayı hiçbir sonuç vermediği, ocakların taşlarının alenen karyeliler tarafından çalınarak sevk olunduğu, hatta iki gün evvel altı bin taşın yüklendiği iki mavnanın yola çıktığının gizlice öğrenildiği, bu konuda mahalli memurlara yapılan şikâyetlerin ve müracaatların adeta sahipsiz bir memleketde bulunulmuş gibi katiyyen nazar-1 dikkate alınmadığı, bu halin büyük bir gadre sebep olduğu, ayrıca durumun Meşruti hükümetin şan ve şerefine de yakışmadığ 1 , bu konuda şiddetli ve etkili tedbirler alınması konusunda kaza kaymakamının mecbur edilmesi hususunda, masrafları kendisine ait olmak üzere nezaret tarafından Karesi Mutasarrıflığı'na telgraf çekilmesi isteği gibi hususlar yer almaktaydi ${ }^{21}$.

Ocaklardan taş kaçırma işi ile ilgili şikâyetler devam etmiş, Balaban taş ocaklarından yirmi üç bin taşın gemi ve mavnalara yüklenerek tezkiresiz olarak kaçırıldığı ileri sürülmüştür22.

Taş kaçırma işi ile ilgili olarak, durum Karesi Mutasarrıflı̆̆ı'na sorulmuş, Karesi Mutasarrıflığı'ndan 16 Nisan 1910 tarihinde gelen cevapta, çalındığı iddia olunan taşların köylüler tarafından imal edildiği, bundan dolayı şikayetçinin bir diyeceği varsa mahkemeye müracaat etmesi gerektiği bildirilmiştir²3.

Karesi Mutasarrıflı̆̆ı'nın bu cevabı üzerine, Gustave Couteaux, imtiyazı kendisinde bulunan taş ocaklarından, başkalarının taş imal etme ve nakletmeye tabiatıyla yetkili olamayacaklarını beyan ederek, hukukunun muhafazasını ısrarlı bir şekilde talep etmeye devam etmiştir.

Bu gelişmeler üzerine Dahiliye Nezareti, 21 Nisan 1910 tarihinde, işin gittikçe kötüye gittiğini fark ederek, olayın sebeplerini öğrenmek istemiş, taş ocaklarının şimdiye kadar kimin uhdesinde olduğunun, tasarruf haklarında bir anlaşmazlık çıkıp çıkmadığının, imtiyaz altında bulunan bu ocaklarda ahalinin kendi kendine taş imal ve nakletmeye yetkileri olup olmadığının araştırılarak bildirilmesini Orman, Meadin ve Ziraat Nezareti'nden istemiştir²4.

Orman, Meadin ve Ziraat Nezareti, Kilise cemiyeti ile Couteaux biraderler arasında anlaşmazlığı çözmek üzere Karesi Sancağı Mutasarrıflığı ve Defter-i Hakani Nezareti ile haberleşmeye başlamıştır ${ }^{25}$.

Karesi Mutasarrıflığı, Dahiliye Nezareti'ne de konuyla ilgili ayrıntılı bilgiler vermiştir. Gustave Couteaux ile Ermeni köylüler arasında tartışma konusu olan Balaban ocakları hududu hakkında, mahallince yapılan tetkikatı içeren evrak, Liva İdare Meclisi'nce

21 BOA, DH.MUI, 22-2/56-10; BOA, DH.MUI, 22-2/56-11.

22 BOA, DH.MUI, 22-2/56-12.

23 BOA, DH.MUI, 22-2/56-18.

24 BOA, DH.MUI, 22-2/56-16.

25 BOA, DH.MUI, 22-2/56-20. 
incelenmiş, mezkur Balaban ocağı hududu bitişiğinde olup, doksan dokuz senesinde yapılan yoklamada, kilise mütevellisi Manuk adına iki yüz guruş bedel ile kaydettirilen arazinin, sırf mezarlık olduğu ve ziraate uygun bir yer olmadığından, nizama uygun olarak tasarruf hakkının sabit olmadığına karar verilmiş, Ermeni köylülerin bu konudaki iddiaları dikkate alınmayarak, taş ocaklarına müdahalelerinin engellenmesine karar verilerek, durum Bandırma Kaymakamlığı'na bildirilmiştir.

Defter-i Hakani Nezareti'nin Liva Defter-i Hakani memurluğu da Ermeni köyünde kiliseye vakıf olarak verilen ve doksan dokuz senesinde, mütevellisi Manuk adına kaydedilen yere, senet verilmesinin kanuna uygun olmadığını ve Manuk'un araziyi hiçbir sûretle tasarrufa hak ve salahiyeti bulunmadığını bildirmiş, durum Bandırma kazası kaymakamlığına 11 Mayıs 1910 tarihinde tebliğ edilmiştir ${ }^{26}$.

1910 yılı Haziran ayında Orman ve Meadin Nezareti, Couteaux kardeşlerin müracaatları ve yerel birimlerden gelen bilgiler üzerine, genellikle taşçı olan karye ahalisinin imal ve ihraç ettikleri paket taşlarının İstanbul, Edirne ve diğer şehirlere nakledilmesini yasaklamıştır. Sonrasında Maden Müdürü Ziya Bey ile Hukuk Müşaviri Sınabyan Efendi tarafından düzenlenen rapora dayanarak bu ocaklarda çalışmakta olan Ermeni ahalinin taş işlemelerini yasaklamıştır ${ }^{27}$.

Alınan bu kararların ardından 1910 yılı yazında Gustave Couteaux ile Ermeni köylüler arasında tartışma konusu olan taş ocaklarında fiili saldırılar başlamıştır. Taş ocaklarının bulunduğu mevkide, Couteaux kardeşlerin adamları, işçilerin kalması için kulübe inşa ederken, Ermeni köylülerin saldırısına uğramışlardır. Kulübenin inşa edildiği yerin, kiliseye ait olduğu ve kilise mütevellisi adına senedi bulunduğu iddia edilerek, köy ahalisinden beş on kişi kulübe inşasıyla meşgul olan işçilerin üzerlerine gidip taş ve toprak atmak suretiyle kovalamışlar, bu sırada işçilerden iki kişiyi yakalayarak darb etmişlerdir.

Saldırıya uğradıktan sonra kaçan Couteaux'nun adamlarından biri, yetkililere giderek olayı haber vermiş, olay yerine tahkik memuru ve yeterli miktarda kuvvet gönderilmiş, olaya karışanlar yakalanarak adli makamlara teslim edilmiştir.

Alınan tedbirlerle köylülerin saldırıları önlenmiş, köyün ihtiyar heyeti ve kilise cemiyeti de çağrılarak bu gibi saldırılarda bulunmamaları, bu konuda bir iddiaları var ise hükümete müracaat etmeleri gerektiği söylenmiş, bundan sonra da tecavüzlerde bulunmayacaklarına dair teminat alınmıştır ${ }^{28}$.

26 "28 Nisan sene [1]326/11 Mayls 1910 tarih ve seksen iki numaralı arîzaya zeyldir. Bandırma Kazâsı'nın Ermeni karyesinde Sultan Bayezid vakfindan olan mahallin kiliseye vakif olarak doksandokuz senesinde mütevellîsi Manuk nâmına yoklamada kaydıyla sened i 'tâsı muvâfik-ı kânûn olmadığından merkûmun mezkûr arâzîyi hiçbir sûretle tasarrufa hak ve salâhiyeti olmadiğı Defter-i Hâkânî Nezâret-i aliyyesinin livâ defter-i hâkâni me'mûrluğundan teblî̆g olunan tahrîrât-ı aliyyesinde iş'âr buyurulmuş ve keyfiyet kazâ-i mezkûr kaymakamlığına teblîğ edilmiştir" BOA, DH.MUİ, 22-2/56-13.

27 BOA, ŞD, 548/35-4-2.

28 BOA, DH.MUI, 111/60-2. 
Bandırma'da taş ocaklarında saldırıya uğrayanlardan bir grup, Dahiliye Nezareti'ne gönderdikleri 6 Temmuz 1910 tarihli telgrafta olayın ayrıntılarını anlatmışlardır. Buna göre; işçiler taş ocağında çalışmakta iken, Kilise Meclisi Reisi Bozanet oğlu Manuk, yanında kilise cemiyeti azaları ve kalabalık bir grupla işçilerin üzerlerine hücum etmişler, katletmek derecesinde darb etmişler, köylerinde Couteaux kardeşlerin adamlarından hiçbirini yaşatmayacaklarını söylemişlerdir. Olay adı geçen köyün avukatı Sebuh Efendi'nin İstanbul'dan köye dönmesi ile gerçekleşmiştir. Saldırıya uğrayanlar, olayın teşvik sonucu olduğunu ve Ermeni Murahhasası Rahib Karabet Efendi’nin bu işte teşvikinin olabileceğini iddia etmişler, bu olayın gerçekleşeceğinin iki gün öncesinden emarelerinin görüldüğünü, gerçekleşmeden önce, önlenmesi hususunda, Bandırma Kaymakamlı̆̆g'na müracaat edildiğini, bu tarz olaylara meydan verilmemesinin köy muhtarına hususi bir tezkire ile ayrıca bildirildiğine işaret etmişler, canlarının muhafazası için köyde daimi surette jandarma bulundurulmasını talep etmişlerdir ${ }^{29}$. Saldırıya uğrayanların olaydan sonra yaptıkları müracaat üzerine, gereği yapılmış, olaylara karışanlar yakalanarak adliyeye teslim edilmiştir ${ }^{30}$.

Saldırıya uğrayanların köyde daimi surette jandarma bulunması talebiyle ilgili olarak Dahiliye Nezareti hemen harekete geçmiş, Karesi Mutasarrıflı̆̆ı'na gönderilen 14 Temmuz 1910 tarihli yazıda, olayın gerçekleşmesinin, taş ocakları bölgesinde daimi surette jandarma bulunmamasından kaynaklandığı yolundaki şikâyetlerden bahsederek, taş ocaklarında çalışmakta olan işçilerin yeni bir saldırıya uğramaması için, orada jandarma ikamesi gerekli görüldüğü takdirde, icabının yapılmasını istemiştir ${ }^{31}$.

Dahiliye Nezareti, Ermeni köyündeki taş ocaklarının jandarma ile muhafazası hususunu bir taraftan Harbiye Nezareti'ne yazarken, diğer taraftan da Karesi Mutasarrıflığı'nı uyarmaya devam etmiş, işçilerin ahali tarafından tekrar silah ile tehdit edilmeye başlandığı yolunda haberler alındığından, taş ocakları bölgesinin muhafaza altına alınmasını istemiştir ${ }^{32}$.

Karesi Mutasarrıflığı, Ermeni köyünde bulunan taş ocaklarında çeşitli saldırı ve taarruz fiilleri olduğundan orada bir karakol kurulmasını ve daimî surette jandarma bulundurulması için liva jandarma kumandanlığına emir verdirilmesini istemiş ${ }^{33}$, Dahiliye Nezareti de, bu isteği Harbiye Nezareti’ne bildirerek gereğinin yapılmasını istemiştir ${ }^{34}$.

29 BOA, DH.MUI, 111/60-3.

30 BOA, DH.MUI, 111/60-7.

31 BOA, DH.MUI, 111/60-6.

32 Galata'da mukîm Mösyö Couteaux Birâderleri Vekîlinden Dâhiliye Nezâret-i Celîlesine 22 Ağustos 1910 tarihli yazı, “...ahîren Ermeni köyünden aldığımız telgrafnâme ve mektuplar me’âllerine nazaran ahâli-i merkûme yine adamlarımızın hânelerini taşlamaya ve silah ile tehdîde tasaddî etmekde bulunmakla yine bir kötü tehlikeye intizar etmekde olduklarından bu yüzden yeniden zuhûr edecek fenâlı̆̆ın mes 'ûliyeti hükûmet-i mahalliyeye â'id ise de bunun önü alınması neye mütevakkıf hemân icrâsı ve jandarma hakkında Bâb-l Seraskerîden karar verilinceye değin mahall-i mezkûrun taht-ı muhâfazaya alınması bâbında emr ü fermân". BOA, DH.MUI, 111/60-8; BOA, DH.MUI, 111/60-9.

33 BOA, DH.MUI, 111/60-10; Bandırma körfezindeki Ermeni köyüne karakol yapılmasıly ilgili olarak çalışmalar yapılmış, inşaatla ilgili olarak 1 Haziran 1904 tarihinde padişah iradesi çıkmıştı. BOA, İ.AS, 51/25-2.

34 BOA, DH.MUI, 111/60-11. 
Bandırma'da Ermeni köyündeki taş ocakları ile ilgili mücadele ilerleyen yıllarda da devam etmiştir. 9 Kasım 1913 tarihinde Şura-yı Devlet/Maliye ve Nafia dairelerinde alınan bir karar konunun çözümlendiği yolundaki düşünceleri kuvvetlendirmektedir.

Buna göre; Şura-yı Devlet/Maliye ve Nafia dairelerinde yapılan incelemelerden sonra, Bandırma kazası dahilinde Ermeni köyündeki taş ocaklarının bulunduğu arazinin kilise vakfından olduğu, mütevellisi Manuk adına bedel-i misliyle kaydedildiği ve geçici ilmuhaberinin verildiği, kimsenin uhdesinde olmadığı zannedilerek, orada taş ocakları açmak üzere Maden İdaresi'nce 23 Temmuz 1890 tarihinde Karabella'ya ruhsatname verildiği, bu ruhsatnamenin, ondan Mösyö Mortman’a, son olarak da Couteaux kardeşlere devrolunduğu, verilen ruhsatnamenin tarihinin köylülere verilen geçici ilmuhaberlerin tarihinden 1, yoklama defterine nisbetle 7 sene sonra olmasından dolayı, Couteaux kardeşlerin bu yerlerdeki tasarruf hukuklarına dair iddia ve taarruzlarına iltifat edilemeyeceği, bu konuda iddiası bulunanların mahkeme-i aidesine müracaat ederek, dava açmakta serbest bulundukları, arazi-i mezkurenin Manuk veresesi adına intikal muamelesinden başka kanunen yapılacak bir muamele olmadı ğ sonucuna varılmıştır ${ }^{35}$.

\section{Birinci Dünya Savaşı Yıllarında Bandırma'daki Taş Ocaklarının Durumu}

Bandırma'da Müslümanlarla Ermeniler uzun süre bir arada yaşamışlar, fakat Osmanlı Devleti'nin son dönemlerinde bu ilişkiler bozulmaya başlamış, Türklerle Ermeniler arasındaki güven duygusu ortadan kalkmıştır.

Birinci Dünya Savaşı yıllarında Osmanlı Devleti’nin gerçekleştirdiği sevk ve iskandan Bandırma Ermenileri de etkilenmiş, nüfusun büyük bir kısmı ülkenin başka coğrafyalarına sevk ve iskân edilmiştir. Karesi liva merkezindeki Ermenilerin sevkleri ilk olarak 1915 yılı Ağustos ayı başlarında gündeme gelmiş, sadece Katolik Ermeniler bu sevkten istisna tutulmuştur. Bandırma Ermenilerinin sevkine hemen başlanılmamış, Karesi ve civarı Ermenileri naklolunduktan sonra Bandırma Ermenilerinin sevkine başlanılmış ve bunların büyük bir kısmı sevk ve iskâna tâbi tutulmuştur.

Karesi Livası dahilindeki sevk ve iskân uygulaması başladığında, Bandırma kazasında yaşayan Ermeni nüfusu toplam 5.232 kişiden ibarettir. Erdek'te 1.094, Bandırma'da 4.032'si Grogeryen, 106’sı Katolik olmak üzere toplam 4.138 Ermeni yaşamaktaydı.

Karesi livasındaki Ermenilerin ihracı ve kendilerinin belirlenen mıntıkalara sevkleri ilk olarak 5 Ağustos 1915 tarihinde Dahiliye Nezareti'nden vilayetlere gönderilen bir telgrafla gündeme gelmiştir. Sevk ve iskân uygulaması bittiğinde Bandırma dahilinde toplam 721

35 BOA, BEO, 4234/317478-2. 
Ermeni kalmış, bunların 421'i asker ailesi, 113'ü Katolik ve Protestan, 39'u özel emir üzerine yerinde bırakılanlar, 148 tanesi oradaki yerli ve yabanc1 Ermenilerdir ${ }^{36}$.

Ermenilerin sevk ve iskâna tâbi tutulması Bandırma Ermeni köyünü ve taş ocaklarının durumunu da etkilemiştir. Sevk ve iskân öncesi Osmanlı tebaasından Ermeni murahhası Karabet adına açılmasına izin verilen bu ocaklar Değirmenyanı, Eskibağlar, Tabakalar, Eskiköy ve Altanar mevkilerinde bulunuyordu. Başta ruhsat sahibi Karabet olmak üzere taş ocaklarından istifade edenler sevk ve iskân kanunu gereğince sevk ve iskâna tâbi tutularak Bandırma'dan ayrılmak zorunda kalmışlardır. Ahalinin sevk ve iskâna tâbi tutulmasından sonra taş ocakları boş kalmış ve işletilememiştir.

Şehremaneti, İstanbul vilayetinin önemli noktalarının ve caddelerinin acilen tamir edilmesi ve yenilenmesi gereken kaldırımları için, parke taşı ihtiyacını Bandırma' da taş ocağı işleterek karşılamak istemiştir. Emanet parke taşları yüzünden senelerden beri karşı karşıya kaldığı zorlukların, birkaç ocağın müstakil olarak işlettirilmesi suretiyle giderilebileceğini, bunun için de bu ocakların, ruhsatının ve işletmeciliğinin Şehremaneti'ne verilmesini istemiştir ${ }^{37}$.

Bunun için kanuni mevzuatın uygun olduğunu belirtmiş, Ticaret ve Ziraat Nezareti’ne başvurarak işi çözmek istemiştir. Ticaret ve Ziraat Nezareti ise granit ocaklarının sahipli arazi olduğunu belirtmiş, nezaretin doğrudan tasarruf edemeyeceğini, bu arazilerin öncelikli olarak mahalli Emval-i Metruke Tasfiye Komisyonu marifetiyle Şehremaneti'ne devredilmesinin uygun olacağını bildirmiştir ${ }^{38}$. Şehremaneti, ocakları hemen işletmek isterse, aylık olarak belirlenecek kira bedeli karşılığında ocakları çalıştırmaya başlayacaktı ${ }^{39}$. Karasi Muhasebeciliği ve Meclis idaresi, granit taş ocağından çıkarılacak her bir taş başına yarım para ödenmesini istemiş ${ }^{40}$, Şehremaneti de bu teklifi kabul etmiş ${ }^{41}$, böylece taş ocakları belirtilen şartlarda Maliye Nezareti vasıtasıyla Şehremaneti'ne kiralanmıştır ${ }^{42}$.

Mütareke döneminde de taş ocaklarıyla ilgili yazışmalar devam etmiştir. Mondros Mütarekesi'nin imzalanmasından sonra, İstanbul İtilaf Devletleri’nin kontrolüne girmiş, İstanbul'da İtilaf devletleri yüksek komiserlikleri kurulmuştu. Bu komiserliklerden biri de İtalya Fevkalade Komiserliği idi.

İtalya vatandaşı olup Roma'da ikamet eden Dominique Corpi ve Belçikalı Couteaux kardeşler, Bandırma'da müştereken işlettikleri taş ocaklarının savaş zamanında zarar gördügüüü iddia etmişler, konuyla ilgili bir dilekçeyi İtalya Fevkalade Komiserliği’ne

36 BOA, DH.EUM.2.Şb, 74/34.

37 BOA, DH.UMVM, 79/30-1.

38 BOA, DH.UMVM, 79/30-3.

39 BOA, DH.UMVM, 79/30-5.

40 BOA, DH.UMVM, 79/30-9.

41 BOA, DH.UMVM, 79/30-11.

42 BOA, DH.UMVM, 79/30-13. 
vermişler, bunun üzerine bir komisyon oluşturulmuş, bu komisyona Hikmet Bey adında bir Türk mimar da katılmış ve Bandırma'ya gönderilerek, taş ocakları ve işletmedeki alet ve edavatın, mevcut iki evin durumu ve uğradığı hasarlar tespit edilmiştir ${ }^{43}$. Tespit edilen hasarlarla ilgili olarak ne gibi bir işlem yapıldığına dair bilgiye rastlanmamıştır.

İtalya Fevkalade Komiserliği, 23 Haziran 1921 tarihinde verdiği bir takrirde de, Birinci Dünya Savaşı sırasında, 1915 senesinin Mart ve Nisan aylarında, Dominique Corpi ve Belçikalı Couteaux kardeşlerin işlettikleri ocaklardan Levazımat-ı Umumiye-i Askeriyye İdaresi'nin Sevkiyat Müdürlüğü tarafından, ücreti ödenmeksizin 324.773 adet kaldırım taşına el konulduğunu ve bu taşların İstanbul'a gönderildiğini, bu taşlardan 40.000 adedinin halen kullanılmadığını ve kullanılmayan bu taşların ilgili kişilere iadesini istemiştir ${ }^{44}$. Aradan üç ay geçtikten sonra, 12 Eylül 1921 tarihinde yeni bir takrir veren İtalya Fevkalade Komiserliği, taşların halen daha iade edilmediğini, 20 gün içinde iade edilmezse, zorla alınacağını Hariciye Nezareti'ne bildirmiştir ${ }^{45}$. Maliye Nezareti bu taşların iadesinin kanunen mümkün olmadığına dair görüşünü 29 Eylül 1921 tarihide açıklamış ${ }^{46}$, buna rağmen Meclis-i Vükela mezkûr taşların iadesinin zaruri olduğu yolunda karar almıştır ${ }^{47}$. Bu karar üzerine elde kalan taşlardan 21.600 adedinin adı geçenlere teslim edilmesi, ellerinde bulunan Tekalif-i Harbiyye mazbatasından verilen taşların adedinin düşülerek, mazbatanın düzenlenmesi, taşların teslim edildiğine dair tasdikli bir makbuz senedi alınması 7 Aralık 1921 tarihinde yetkililerden istenmiştir ${ }^{48}$.

\section{Milli Mücadele Sonrasında Bandırma'daki Taș Ocaklarının Durumu}

1923 yılı başlarında, önceki imtiyaz sahibi Belçikalı Couteaux, ocakları yeniden işletebilmek için girişimlerde bulunmuş, mühendis ve fen müdürü Dominique Corpi ve idare müdürü Raffaele Bernieri'nin Bandırma'ya gitmesine izin verilmesine dair bir yazı göndermiştir ${ }^{49}$. Sonrasında ise İtalya Fevkalade Komiserliği 3 Ocak 1923 tarihinde bir takrir vermiş, Erdek ve Bandırma kazaları dahilindeki taş ocaklarının işlerini yapan, Mösyö Raffaele ile Joseph, Achille, Antonio isimlerindeki üç çocuğu olan Bernieri ailesinin, taş ocaklarını işletmek için gerekli tedarikatta bulunmak ve evvelce madenden çıkarılan granit kaldırım taşlarını Dersaadet'e nakletmek üzere Erdek ve Bandırma’ya gitmesine izin verilmesini talep etmiştir ${ }^{50}$.

Ankara'da Büyük Millet Meclisi Hükümeti Hariciye Vekaleti önce, İtalya tebaasından Dominique Corpi ile diğerlerinin işçi sıfatıyla orada bulunduklarını, isterlerse Bandırma'ya

43 BOA, HR.SYS, 2576/2-6, 7.

44 BOA, HR.SYS, 2576/2-11.

45 BOA, HR.SYS, 2576/2-15.

46 BOA, HR.SYS, 2576/2- 20 .

47 BOA, HR.SYS, 2576/2- 23 .

48 BOA, HR.SYS, 2576/2- 25.

49 BOA, HR.IMM, 40/5-9.

50 BOA, HR.IMM, 40/5-2. 
gitmelerinde mahzur olmadığını bildirmiştir ${ }^{51}$. Fakat Hariciye Vekaleti, iki gün sonra yeni bir yazı göndererek, Dominique Corpi ile diğerlerinin, Bandırma’ya gitmeleri için verdiği izni iptal etmiştir. Hariciye Vekaleti, buna gerekçe olarak, Dominique Corpi'ye, 1917 yılında mülga Ticaret ve Ziraat Nezareti'nce, granit ocağını 5 sene müddetle işletme hakkı verildiğini, fakat 7 Haziran 1921 tarihinde neşredilen kanun gereğince, 16 Mart 1920 tarihinden sonra İstanbul hükümetleri tarafından alınan kararların yok sayıldığını, bundan dolayı ocaklar üzerinde hiçbir hukuki hakkı olmayan kişilerin oralara gitmelerine gerek kalmadığını göstermiştir ${ }^{52}$.

\section{Sonuç}

Bandırma kazasına bağlı Preme Nahiyesi'ndeki Ermeni köyünde bulunan taş ocaklarının işletilmesi konusu, Osmanlı bürokrasini uğraştıran bir mesele olarak gündeme gelmiştir. Bandırma kazasında Ermeni köyünde bulunan taş ocaklarıyla ilgili sıkıntıların, taş ocaklarının işletme hakkının yabancılara verilmesinden itibaren belgelere yansıdı̆̆ı görülmektedir. Taş ocaklarıyla ilgili işletme ruhsatlarının yabancılara verilmesinden sonra taraflar arasında anlaşmazlıklar baş göstermiştir. Her iki taraf da taş ocaklarından taş çıkarıp İstanbul'a nakletmişler, bu taşların kendilerine ait olduğunu iddia etmişler ve bundan dolayı aralarında kavga çıkmıştır. 1910 yılı Haziran ayında Orman Nezareti’nin, taş işiyle uğraşan köy ahalisinin imal ve ihraç ettikleri taşları İstanbul, Edirne ve diğer Osmanlı şehirlerine naklini yasaklamasıyla birlikte mücadele daha da kızışmıştır. Köyün Ermeni ahalisi taş ocaklarına müdahale etmiş, taşların gönderilmesine engel olmuş, daha sonrasında iş fiili saldırılara kadar varmıştır. Bu saldırıların önlenmesi ve asayişin sağlanabilmesi için köye bir karakol kurulması için girişimlerde bulunulmuştur. Birinci Dünya Savaşı yıllarında ise Ermenilerin Bandırma'dan sevklerinden sonra, taş ocakları Şehremaneti'ne kiralanmıştır. Milli Mücadele sonrası ise Büyük Millet Meclisi Hükümeti, 16 Mart 1920 tarihinden sonra İstanbul hükümetleri tarafından kabul edilen kararları yok saydığından, hiçbir yabancıya taş ocaklarını işletme imtiyazı vermemiştir.

Hakem Değerlendirmesi: Dış bağımsız.

Çıkar Çatışması: Yazar çıkar çatışması bildirmemiştir.

Finansal Destek: Yazar bu çalışma için finansal destek almadığını beyan etmiştir.

Peer-review: Externally peer-reviewed.

Conflict of Interest: The author has no conflict of interest to declare.

Grant Support: The author declared that this study has received no financial support.

51 BOA, HR.İM, 40/5-7.

52 BOA, HR.İM, 40/5-8. 


\section{Kaynakça/References}

\section{Arşiv Vesikaları}

Türkiye Cumhuriyeti Cumhurbaşkanlığı Devlet Arşivleri Başkanlığı Osman Arşivi (BOA)

Bab-1 Ali Evrak Odası (BEO)

Dâhiliye Nezareti

Mektubi Kalemi (DH.MKT.)

Muhaberât-1 Umumiye İdaresi Belgeleri (DH.MUI.)

Umur-1 Mahalliye ve Vilayat Müdürlüğü Evrakı (DH.UMVM.)

Emniyet-i Umumiye Müdüriyeti İkinci Şube (DH.EUM.2.Şb.)

Hariciye Nezareti

Hukuk Müşavirliği İstişare Odası Evrakı (HR.HMŞ.IŞSO.)

Siyasi İstanbul Murahhaslığı (HR.İM.)

Siyasi Kalemi (HR.SYS.)

Tercüme Odası Evrakı (HR.TO.)

İrade-Askeri (İ.AS.)

Şura-yı Devlet Evrakı (ŞD.)

\section{Araştırma Eserler}

Kanberoğlu, Nesrin, “Osmanlı Devletinin Zımpara Madenleri Hakkında Bir Tetkik (1908-1918)", Journal of History Studies, c. X, Kasim 2018, s. 185-205.

Keskin, Özkan, “Osmanlı Devleti’nde Maden Hukukunun Tekamülü (1861-1906)”, Ankara Üniversitesi Osmanl Tarihi Araştırma ve Uygulama Merkezi Dergisi (OTAM), say1 29, Ankara 2011, s. 125-147.

Memalik-i Osmaniyye'nin 1330 Senesi Nüfus İstatistiği, Dersaadet 1336.

Öntuğ, Murat, "Balıkesir'deki Ermeni Kilisesi ve Mektep Açma Faaliyetleri”, OTAM, sayı 19, Ankara 2006, s. 344-366.

Taşlıgil, Nuran - Güven Şahin, "Yapı Malzemesi Olarak Kullanılan Türkiye Doğal Taşlarının İktisadi Coğrafya Odağında Analizi”, Marmara Coğrafya Dergisi, sayı 33, Ocak 2016, s. 607-640. 


\section{Ek}

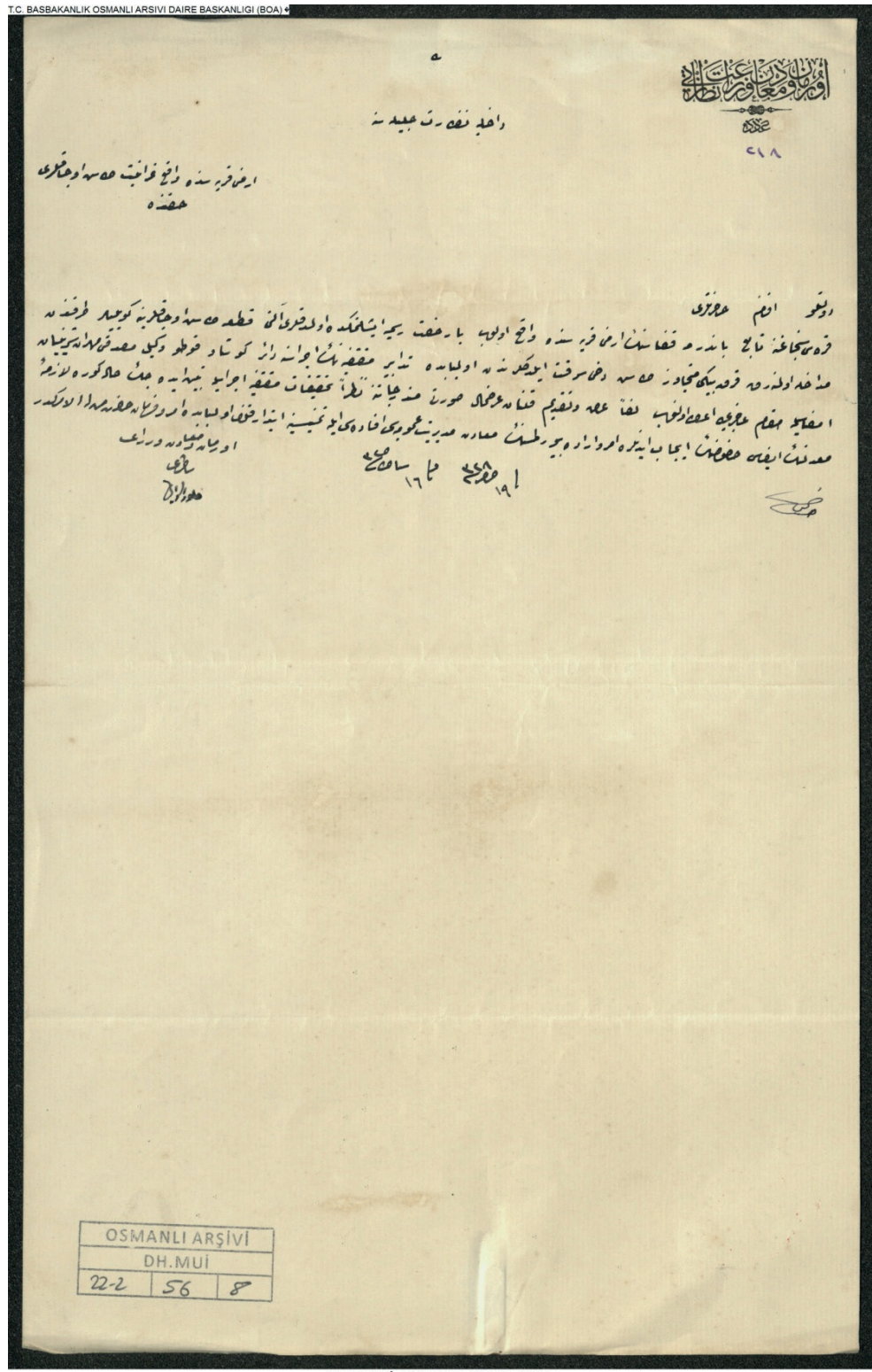

DH.MUI..00022.2.00056.008 


\section{Orman ve Me'âdin ve Zirâ'at Nezâreti}

Aded

218

Ermeni karyesinde vâki‘ granit taş ocakları hakkında.

Dâhiliye Nezâret-i Celîlesine

Devletlü efendim hazretleri

Karesi Sancağı'na tâbi‘ Bandırma Kazâsı'nın Ermeni karyesinde vâkî‘ olup bâ-ruhsat-1 resmiye işletmekde oldukları altı kıt' a taş ocaklarına köylüler tarafından müdâhale olunarak kırkbini mütecâviz taş dahi sirkat eylediklerinden ol-bâbda tedâbîr-i mukteziyenin icrâsına dâ'ir Gustav Koto vekîl-i musaddakı Mihran Şirinyan imzâsıyla makâm-1 âcîzîye i‘tâ olunup leffen arz ve takdîm kılınan arzuhal sûreti mündericâtına nazaran tahkîkât-1 mukteziye icrâsıyla tebeyyün edecek hâle göre lâzime-i ma'deletin îfâsı husûsunun îcâb edenlere emir ve irâde buyurulmasının Me'âdin Müdüriyet-i Umûmiyyesi ifâdesi ile temennîsine ibtidâr kılındı. Ol-bâbda emr ü fermân hazret-i men lehü’l-emrindir.

Fî 19 Safer sene [1]328 ve Fî 16 Şubat sene [1]325

Orman ve Me‘âdin ve Zirâ‘at

Nâzırı

İmza 
